ISSN 0258-7122

Bangladesh J. Agril. Res. 36(2) : 357-367, June 2011

\title{
EFFECT OF NITROGEN FOR YIELD MAXIMIZATION OF GARLIC IN OLD BRAHMAPUTRA FLOOD PLAIN SOIL
}

\author{
M. S. ZAMAN ${ }^{1}$, M. A. HASHEM ${ }^{2}$, M. JAHIRUDDIN ${ }^{2}$ AND M. A. RAHIM ${ }^{3}$ \\ Abstract \\ The experiment was conducted for two consecutive rabi seasons of 2005-06 and \\ 2006-07 at the Regional Agricultural Research Station (RARS), Jamalpur to find \\ out an optimum dose of nitrogen for the production of garlic (cv. Jamalpur \\ local). There were six levels of nitrogen viz., 0, 50, 100, 150, 200, and 250 \\ $\mathrm{kg} / \mathrm{ha}$. The experiment was laid out in randomized complete design with three \\ replications. Results revealed that nitrogen had significant effects on almost all \\ the parameters studied. Nitrogen @ $150 \mathrm{~kg} / \mathrm{h}$ a produced the highest bulb yield \\ (6.75 t/ha in 2005-06 and 7.19 t/ha in 2006-07) and there was a reduction of \\ yield with further increment of nitrogen level. The control treatment receiving \\ no fertilizer produced the lowest bulb yield in both the years. The yield benefit \\ for $150 \mathrm{~kg} \mathrm{~N} / \mathrm{ha}$ was $40 \%$ than the yield obtained from nitrogen control \\ treatment when average of two years' yield is considered.
}

Keywords: Nitrogen, garlic, growth, bulb yield.

\section{Introduction}

Garlic (Allium sativum L.) is the second most important cultivated Allium after onion. In Bangladesh, it ranks third next to onion and chilli. Garlic is an integral part of daily diet of the people of the Asian countries including Bangladesh. It is cultivated as spice and also used as medicine. Garlic is grown all over Bangladesh in the rabi season and consumed by most of the people (Rashid, 1996). It grows best on well drained soils high in organic matter. Sandy loam or loam soil is the most ideal texture for garlic. The requirement of nitrogen for garlic production may vary with soil type, the previous crop grown, the amount of organic matter present and the climatic conditions during the crop growing season. Nitrogen is one of the major essential nutrient elements that contributes a lot for the production of crop. Most of the agricultural lands in Bangladesh are deficient in nitrogen due to low level of organic matter. Imbalanced and poorly monitored nitrogen application limits yields and induces large losses of reactive nitrogen to the environment. (Cassman et al., 2002). Nitrogen increased the rates of leaf initiation and extension of garlic in early growth (Garcia, 1980; Koltunov, 1984). It improved bulb growth and development (Buwalda and Freeman, 1987, Fritsch et al., 1990; Hossain, 1997; Garcia et al., 1994). Lachica (1982) reported

${ }^{1}$ Senior Scientific Officer, RARS, Bangladesh Agricultural Research Institute (BARI), Jamalpur; ${ }^{2}$ Professor, Department of Soil Science, Bangladesh Agricultural University (BAU), Mymensingh, ${ }^{3}$ Professor. Depeartment of Horticulture, BAU, Mymensingh, Bangladesh. 
that the growth and yield of garlic increased significantly as the levels of nitrogen increased from 0 to $400 \mathrm{~kg} / \mathrm{ha}$ beyond which yield declined. Hedge (1988) showed that the dry matter production of bulb and bulb yield were increased due to nitrogen application. The positive and significant response of garlic to applied nitrogen has also been reported by many authors (Brabma and Yousuf, 2008; Talukder et al., 1998; Uddin, 1993; Setty et al. 1989; Soto, 1988). The average yield of garlic in Bangladesh is $3.82 \mathrm{t} / \mathrm{ha}$, which is very low (BBS, 2006) compared to major garlic producing countries of the world. Lower yield of garlic in Bangladesh and similar tropical countries is subjected to many factors, deficiency of nutrients, especially nitrogen is one of them. Keeping this in mind, the present research work has been undertaken to find out an optimum dose of nitrogen for yield maximization of garlic in Old Brahmaputra Floodplain soil of Jamalpur.

\section{Materials and Method}

The experiment was conducted for two consecutive rabi seasons of 2005-06 and 2006-07 at the research field of Regional Agricultural Research Station (RARS), Jamalpur to find out an optimum dose of nitrogen for the production of garlic. The soil of the experimental field was silt loam in texture belonging to Sonatola Soil Series under the AEZ 9: Old Brahmaputra Floodplain (FAO, 1971). The land remained fallow in Kharif-II season before initiation of the experiment. Organic matter content of the soil was low. The soil was acidic in nature. Total $\mathrm{N}$ and exchangeable $\mathrm{K}$ status of the soil were also low. The available phosphorus, sulphur, boron, and zinc were found to be either at par or below the critical level (Table 4). Six levels of nitrogen viz., 0, 50, 100, 150, 200, and $250 \mathrm{~kg} / \mathrm{ha}$ were used in the experiment. The fertilizer package $\mathrm{P}_{60} \mathrm{~K}_{120} \mathrm{~S}_{45} \mathrm{Zn}_{4} \mathrm{~B}_{1} \mathrm{~kg} / \mathrm{ha}$ was applied to each plot as blanket dose. The experiment was carried out in randomized complete design with three replications. The unit plot size was $2.0 \mathrm{~m} \times 1.5 \mathrm{~m}$ and the spacing maintained between the rows was $15 \mathrm{~cm}$ and the seed to seed distance was $10 \mathrm{~cm}$. Garlic seeds were planted on first week of November. Intercultural operations were done as and when required. Data on plant growth, yield parameters, and bulb yield were recorded and analyzed through MSTAT programme. The DMRT test was used for mean separations of the studied parameters.

\section{Results and Discussion}

Growth and yield of garlic were significantly influenced by nitrogen fertilization (Table 1). The maximum plant height $(64.7 \mathrm{~cm})$ was recorded in 2005-06 with $200 \mathrm{~kg} \mathrm{~N} / \mathrm{ha}$, which was followed by $150 \mathrm{~kg} \mathrm{~N} / \mathrm{ha}(64.1 \mathrm{~cm})$ and the minimum $(42.4 \mathrm{~cm})$ was recorded in the control plot receiving no fertilizer. Further increase in the level of nitrogen $(250 \mathrm{~kg} / \mathrm{ha})$ decreased the plant height. The result is in agreement with the findings of Setty et al. (1989) and Vachhani and Patel (1993). 
Table 1. Effects of nitrogen on plant height at regular 20-day intervals of garlic during 2005-06 and 2006-07.

\begin{tabular}{|c|c|c|c|c|c|c|c|c|c|c|c|c|}
\hline \multirow{3}{*}{$\begin{array}{c}\text { Nitrogen } \\
\text { (kg/ha) }\end{array}$} & \multicolumn{12}{|c|}{ Plant height $(\mathrm{cm})$ at different DAP } \\
\hline & \multicolumn{6}{|c|}{$2005-06$} & \multicolumn{6}{|c|}{$2006-07$} \\
\hline & 30 & 50 & 70 & 90 & 110 & $\begin{array}{c}\text { At } \\
\text { harvest }\end{array}$ & 30 & 50 & 70 & 90 & 110 & $\begin{array}{c}\text { At } \\
\text { harvest }\end{array}$ \\
\hline 0 & $21.1 \mathrm{~cd}$ & $29.9 \mathrm{~d}$ & $36.5 \mathrm{c}$ & $47.1 \mathrm{c}$ & $50.2 \mathrm{c}$ & $49.0 \mathrm{e}$ & $22.3 \mathrm{~cd}$ & $26.8 \mathrm{~b}$ & $32.1 \mathrm{bc}$ & $43.5 \mathrm{~d}$ & $45.5 \mathrm{~d}$ & $43.1 \mathrm{c}$ \\
\hline 50 & $22.1 \mathrm{~cd}$ & $32.9 \mathrm{c}$ & $40.8 \mathrm{~b}$ & $54.7 \mathrm{~b}$ & $58.2 b$ & $56.6 \mathrm{~d}$ & $22.7 \mathrm{bcd}$ & $31.8 \mathrm{a}$ & $36.9 \mathrm{ab}$ & $50.6 \mathrm{c}$ & $57.0 \mathrm{c}$ & $55.4 \mathrm{~b}$ \\
\hline 100 & $22.6 \mathrm{bc}$ & $33.4 \mathrm{bc}$ & $46.1 \mathrm{a}$ & $57.5 \mathrm{ab}$ & $61.9 \mathrm{a}$ & $61.4 \mathrm{bc}$ & $23.7 \mathrm{abc}$ & $32.3 \mathrm{a}$ & $37.6 \mathrm{a}$ & $55.5 \mathrm{~b}$ & $65.7 \mathrm{~b}$ & $60.3 \mathrm{ab}$ \\
\hline 150 & $23.5 \mathrm{abc}$ & $35.1 \mathrm{ab}$ & $45.1 \mathrm{a}$ & $58.1 \mathrm{ab}$ & $64.1 \mathrm{a}$ & $62.3 \mathrm{ab}$ & $24.4 \mathrm{abc}$ & $33.3 \mathrm{a}$ & $39.2 \mathrm{a}$ & $61.3 \mathrm{a}$ & $70.5 \mathrm{a}$ & $66.3 \mathrm{a}$ \\
\hline 200 & $24.9 \mathrm{ab}$ & $35.4 \mathrm{a}$ & $47.4 \mathrm{a}$ & $60.0 \mathrm{a}$ & $64.6 \mathrm{a}$ & $64.2 \mathrm{a}$ & $24.9 \mathrm{ab}$ & $34.1 \mathrm{a}$ & $40.7 \mathrm{a}$ & $63.5 \mathrm{a}$ & $72.1 \mathrm{a}$ & $66.6 \mathrm{a}$ \\
\hline 250 & $25.4 \mathrm{a}$ & $36.7 \mathrm{a}$ & $46.9 \mathrm{a}$ & $59.5 \mathrm{a}$ & $62.7 \mathrm{a}$ & $59.9 \mathrm{c}$ & $25.3 \mathrm{a}$ & $33.8 \mathrm{a}$ & $38.4 \mathrm{a}$ & $52.2 \mathrm{c}$ & $66.3 \mathrm{~b}$ & $64.5 \mathrm{a}$ \\
\hline Control & $19.9 \mathrm{~d}$ & $26.1 \mathrm{e}$ & $32.7 \mathrm{c}$ & $40.6 \mathrm{~d}$ & $42.4 \mathrm{~d}$ & $40.3 \mathrm{f}$ & $20.9 \mathrm{~d}$ & $24.2 \mathrm{~b}$ & $28.0 \mathrm{c}$ & $38.3 \mathrm{e}$ & $40.7 \mathrm{e}$ & $39.5 \mathrm{c}$ \\
\hline $\mathrm{CV}(\%)$ & 5.10 & 4.23 & 5.31 & 4.69 & 4.94 & 4.97 & 5.09 & 7.95 & 9.30 & 6.33 & 5.87 & 6.38 \\
\hline
\end{tabular}

Figures in a colunm having same letter(s) do not differ significantly at $5 \%$ level of probability.

- Every treatment received $\mathrm{P}_{60} \mathrm{~K}_{120} \mathrm{~S}_{45} \mathrm{Zn}_{4} \mathrm{~B}_{1} \mathrm{~kg} / \mathrm{ha}$. 
Table 2. Effects of nitrogen on number of leaves per plant at regular 20-day intervals of garlic during2005-06 and 2006-07.

\begin{tabular}{|c|c|c|c|c|c|c|c|c|c|c|c|c|}
\hline \multirow{3}{*}{$\begin{array}{l}\text { Nitrogen } \\
(\mathrm{kg} / \mathrm{ha})\end{array}$} & \multicolumn{12}{|c|}{ Number of leaves plant at different DAP } \\
\hline & \multicolumn{6}{|c|}{$2005-06$} & \multicolumn{6}{|c|}{$2006-07$} \\
\hline & 30 & 50 & 70 & 90 & 110 & $\begin{array}{c}\text { At } \\
\text { harvest }\end{array}$ & 30 & 50 & 70 & 90 & 110 & $\begin{array}{c}\text { At } \\
\text { harvest }\end{array}$ \\
\hline 0 & 4.37 & $5.07 \mathrm{bc}$ & $5.87 \mathrm{bc}$ & $7.13 \mathrm{~b}$ & $7.67 \mathrm{~d}$ & $7.60 \mathrm{~b}$ & $4.47 \mathrm{bc}$ & $5.20 \mathrm{ab}$ & $5.91 \mathrm{ab}$ & $6.87 \mathrm{a}$ & $8.40 \mathrm{a}$ & $7.87 \mathrm{a}$ \\
\hline 50 & 4.49 & $5.20 \mathrm{abc}$ & $6.33 \mathrm{ab}$ & $7.36 \mathrm{ab}$ & $7.87 \mathrm{~cd}$ & $7.67 \mathrm{ab}$ & $4.47 \mathrm{bc}$ & $5.27 \mathrm{ab}$ & $6.07 \mathrm{ab}$ & $6.87 \mathrm{a}$ & $8.37 \mathrm{a}$ & $7.87 \mathrm{a}$ \\
\hline 100 & 4.70 & $5.27 \mathrm{abc}$ & $6.60 \mathrm{a}$ & $7.50 \mathrm{a}$ & $8.06 \mathrm{bcd}$ & $7.80 \mathrm{ab}$ & $4.53 \mathrm{bc}$ & $5.27 \mathrm{ab}$ & $6.17 \mathrm{ab}$ & $6.97 \mathrm{a}$ & $7.80 \mathrm{a}$ & $8.13 \mathrm{a}$ \\
\hline 150 & 4.63 & $5.43 \mathrm{ab}$ & $6.67 \mathrm{a}$ & $7.60 \mathrm{a}$ & $8.47 \mathrm{ab}$ & $8.13 \mathrm{a}$ & $4.80 \mathrm{a}$ & $5.70 \mathrm{a}$ & $6.53 \mathrm{a}$ & $6.87 \mathrm{a}$ & $8.13 \mathrm{a}$ & $8.27 \mathrm{a}$ \\
\hline 200 & 4.80 & $5.27 \mathrm{abc}$ & $6.67 \mathrm{a}$ & $7.63 \mathrm{a}$ & $8.53 \mathrm{a}$ & $8.13 \mathrm{a}$ & $4.60 \mathrm{ab}$ & $5.60 \mathrm{a}$ & $6.07 \mathrm{ab}$ & $7.13 \mathrm{a}$ & $8.13 \mathrm{a}$ & $8.27 \mathrm{a}$ \\
\hline 250 & 4.67 & $5.67 \mathrm{a}$ & $6.80 \mathrm{a}$ & $7.63 \mathrm{a}$ & $8.17 \mathrm{abc}$ & $7.87 \mathrm{ab}$ & $4.53 \mathrm{abc}$ & $5.47 \mathrm{a}$ & $6.13 \mathrm{ab}$ & $7.07 \mathrm{a}$ & $8.27 \mathrm{a}$ & $8.20 \mathrm{a}$ \\
\hline Control & 4.33 & $4.73 \mathrm{c}$ & $5.57 \mathrm{c}$ & $5.90 \mathrm{c}$ & $6.57 \mathrm{c}$ & $6.60 \mathrm{c}$ & $4.30 \mathrm{c}$ & $4.83 \mathrm{~b}$ & $5.43 \mathrm{~b}$ & $6.00 \mathrm{~b}$ & $6.40 \mathrm{~b}$ & $6.47 \mathrm{~b}$ \\
\hline $\mathrm{CV}(\%)$ & 5.69 & 5.46 & 4.49 & 4.44 & 4.03 & 4.47 & 5.15 & 5.08 & 6.83 & 5.62 & 5.60 & 5.48 \\
\hline
\end{tabular}

Figures in a column having same letter(s) do not differ significantly at $5 \%$ level of probability.

- Every treatment received $\mathrm{P}_{60} \mathrm{~K}_{120} \mathrm{~S}_{45} \mathrm{Zn}_{4} \mathrm{~B}_{1} \mathrm{~kg} / \mathrm{ha}$. 
Table 3. Effect of different levels of nitrogen on yield parameters of garlic.

\begin{tabular}{|c|c|c|c|c|c|c|c|}
\hline \multirow{2}{*}{$\begin{array}{l}\text { Nitrogen } \\
(\mathrm{kg} / \mathrm{ha})\end{array}$} & \multirow{2}{*}{$\frac{\text { Bulb length }(\mathrm{cm})}{2005-06}$} & \multicolumn{2}{|c|}{ Bulb diameter $(\mathrm{cm})$} & \multicolumn{2}{|c|}{ Wt of single bulb $(\mathrm{g})$} & \multicolumn{2}{|c|}{ No. of cloves/bulb } \\
\hline & & 2006-07 & 2006-07 & 2005-06 & 2006-07 & 2005-06 & 2006-07 \\
\hline 0 & $2.47 \mathrm{c}$ & $2.48 \mathrm{~cd}$ & $2.39 \mathrm{~cd}$ & $11.9 \mathrm{~d}$ & $12.0 \mathrm{c}$ & $15.7 \mathrm{~b}$ & $15.4 \mathrm{bc}$ \\
\hline 50 & $2.86 \mathrm{~b}$ & 2.78 be & $2.57 \mathrm{bcd}$ & $13.0 \mathrm{c}$ & $13.9 \mathrm{bc}$ & $17.5 \mathrm{ab}$ & $17.5 \mathrm{ab}$ \\
\hline 100 & $2.97 \mathrm{ab}$ & $2.89 \mathrm{ab}$ & $2.74 \mathrm{abc}$ & $14.4 \mathrm{~b}$ & $15.8 \mathrm{ab}$ & $19.5 \mathrm{a}$ & $18.9 \mathrm{ab}$ \\
\hline 150 & $3.14 \mathrm{a}$ & $3.22 \mathrm{a}$ & $3.12 \mathrm{a}$ & $16.1 \mathrm{a}$ & $17.4 \mathrm{a}$ & $19.8 \mathrm{a}$ & $20.9 \mathrm{a}$ \\
\hline 200 & $3.04 \mathrm{ab}$ & $3.10 \mathrm{ab}$ & $3.05 \mathrm{ab}$ & $15.3 \mathrm{a}$ & $16.3 \mathrm{a}$ & $19.1 \mathrm{a}$ & $19.9 \mathrm{a}$ \\
\hline 250 & $2.97 \mathrm{ab}$ & $3.05 \mathrm{ab}$ & $3.03 \mathrm{ab}$ & $15.3 \mathrm{a}$ & $15.7 \mathrm{ab}$ & $18.5 \mathrm{ab}$ & $19.6 \mathrm{a}$ \\
\hline Control & $2.18 \mathrm{~d}$ & $2.28 \mathrm{~d}$ & $2.28 \mathrm{~d}$ & $8.39 \mathrm{c}$ & $8.77 \mathrm{~d}$ & $14.0 \mathrm{c}$ & $13.2 \mathrm{c}$ \\
\hline $\mathrm{CV}(\%)$ & 4.16 & 7.04 & 5.92 & 3.64 & 8.03 & 6.81 & 11.1 \\
\hline
\end{tabular}

Figures in a column having same letter(s) do not differ significantly at $5 \%$ level of probability.

- Every treatment received $\mathrm{P}_{60} \mathrm{~K}_{120} \mathrm{~S}_{45} \mathrm{Zn}_{4} \mathrm{~B}_{1} \mathrm{~kg} / \mathrm{ha}$. 
The increase in plant height due to nitrogen application indicates a positive role of nitrogen on plant growth and the soil was deficient in nitrogen. In the case of 2006-07 experiment, the performance of nitrogen showed more or less similar trend as that of 2005-06. In this case, the maximum plant height $(66.8 \mathrm{~cm})$ was also recorded with the same nitrogen dose $200 \mathrm{~kg} \mathrm{~N} / \mathrm{ha}$. Like plant height, the maximum number of leaves per plant (8.53 in 2005-06 and 8.40 a in 2006-07) was recorded with $200 \mathrm{~kg} \mathrm{~N} / \mathrm{ha}$ and the lowest (6.57) was noted in control plots (Table 2). The maximum dry weight of leaves per plant $(2.40 \mathrm{~g})$ and the highest dry weight of single plant (4.33 g) were also obtained from the same nitrogen dose $200 \mathrm{~kg} \mathrm{~N} / \mathrm{ha}$ (Fig. 1 \& 2). Plants grown with $200 \mathrm{~kg} \mathrm{~N} / \mathrm{ha}$ produced the maximum vegetative growth, which possibly enhanced the maximum photosynthetic activity and accumulation of dry matter in plants. Again it was observed that dry weight of leaves per plant and dry weight of single plant increased with the increasing levels of nitrogen up to $200 \mathrm{~kg} / \mathrm{ha}$ and at further higher dose $(250 \mathrm{~kg} \mathrm{~N} / \mathrm{ha})$ it decreased. Similar result was also observed by Hossain (1997).

Table 4. Nutrient status of the initial soil.

\begin{tabular}{lc}
\hline \multicolumn{1}{c|}{ Soil parameters } & Values \\
\hline $\mathrm{pH}(1: 2.5$ Soil-water $)$ & 5.80 \\
Bulk density $\left(\mathrm{g} \mathrm{cm}^{-3}\right)$ & 1.43 \\
Exchangeable $\mathrm{K}(\mathrm{c} \mathrm{mol} / \mathrm{kg})$ & 0.12 \\
Exchangeable $\mathrm{Ca}(\mathrm{c} \mathrm{mol} / \mathrm{kg})$ & 3.60 \\
Exchangeable $\mathrm{Mg}(\mathrm{c} \mathrm{mol} / \mathrm{kg})$ & 1.05 \\
Organic matter $(\%)$ & 1.07 \\
Total N $(\%)$ & 0.06 \\
Available P $(\mathrm{mg} / \mathrm{kg})$ & 14.5 \\
Available S $(\mathrm{mg} / \mathrm{kg})$ & 13.6 \\
Available Zn $(\mathrm{mg} / \mathrm{kg})$ & 1.14 \\
Available B $(\mathrm{mg} / \mathrm{kg})$ & 0.18 \\
\hline
\end{tabular}

Yield contributing characters viz., bulb length, bulb diameter, no. of cloves per plant and single bulb weight increased significantly due to the application of nitrogen in both the years (Table 3). The diameter of bulbs varied from 2.18 to $3.14 \mathrm{~cm}$ in $2005-06$ and 2.28 to $3.22 \mathrm{~cm}$ in 2006-07. The maximum diameter of bulb was found in the plants grown with $150 \mathrm{~kg} \mathrm{~N} / \mathrm{ha}$, further increment of nitrogen dose has led to reduce the bulb diameter. The minimum value was recorded in the control treatment. The result is in agreement with the findings of Rahman et al. (2004) and Setty et al. (1989). Plants grown with $150 \mathrm{~kg}$ N/ha received sufficient nutrient supply which ultimately promoted the growth of 
plants. Data on bulb length of garlic was taken only for the second year (200607) and had followed the pattern similar to that of bulb diameter. The highest length of bulb $(3.12 \mathrm{~cm})$ was recorded in $150 \mathrm{~kg} \mathrm{~N} / \mathrm{ha}$ followed by $200 \mathrm{~kg} \mathrm{~N} / \mathrm{ha}$ $(3.05 \mathrm{~cm})$ and $250 \mathrm{~kg} \mathrm{~N} / \mathrm{ha}(3.03 \mathrm{~cm})$, the later two treatments being statistically identical. The lowest bulb length $(2.28 \mathrm{~cm})$ was found in the control plots that received no fertilizer. The maximum fresh weight of single bulb $(16.1 \mathrm{~g}$ in 200506 and $17.4 \mathrm{~g}$ in 2006-07) was recorded in $150 \mathrm{~kg} / \mathrm{N}$ followed by $200 \mathrm{~kg} \mathrm{~N} / \mathrm{ha}$ (Table 3). The control treatment receiving no fertilizer produced the lowest bulb weight $(8.39 \mathrm{~g}$ and $8.77 \mathrm{~g})$. The result is in accord with the findings of Ali and Huq (1996). It was found that the weight of bulbs increased by $26.3 \%$ in $2005-06$ and $30.8 \%$ in 2006-07 due to $150 \mathrm{~kg}$ N/ha over no nitrogen plots. Plants with 150 $\mathrm{kg} \mathrm{N} / \mathrm{ha}$ gave more vegetative growth as well as number of green leaves, which helped maximum photosynthesis and accumulation of more dry matter in the bulb. This finding is in agreement with the reports of Rahman et al. (2004) and Setty et al. (1989). The highest number of cloves per bulb (19.8 in 2005-06 and 20.9 in 2006-07) was obtained from the plants with $150 \mathrm{~kg} \mathrm{~N} / \mathrm{ha}$ and the lowest (14.0 in 2005-06 and 13.24 in 2006-07) was found in the control treatment (Table 3 ). The number of cloves per bulb showed a trend of slower increase with increasing nitrogen levels from 0 to $150 \mathrm{~kg} / \mathrm{ha}$ and after which it declined. The result is in accord with the findings of Rahman et al. (2004); Hossain (1997) and Talukder (1998).

\section{Bulb yield}

Yield is a complex parameter that results from the interaction of various yield contributing chracters. Bulb yield of garlic increased with increased rate of nitrogen application up to $150 \mathrm{~kg} \mathrm{~N} / \mathrm{ha}$ (6.75 t/ha in 2005-06 and 7.19 t/ha in 200607).There was a reduction in bulb yield with further increase in the level of nitrogen. Production of maximum bulb yield by the application of nitrogen at 150 $\mathrm{kg} / \mathrm{ha}$ might be due to production of taller plants with higher number of leaves leading to increased formation of vegetative structure for nutrient absorption, photosynthesis and increased production of assimilates to fill the sink which result in increased bulb size and weight. The control treatment receiving no fertilizer produced the lowest yield (3.33 t/ha in 2005-06 and 3.24 t/ha in 2006-07). The shortest plant, lowest number of leaves, cloves per bulb, smallest diameter and lowest weight of bulbs in control treatment resulted in lower yield. The yield difference between the highest and the lowest values was 52.8\%. It was found that with increasing nitrogen levels from 0 to $150 \mathrm{~kg} \mathrm{~N} / \mathrm{ha}$ resulted in progressive increase in yield and thereafter the yield declined, which might be due to imbalance of nutrients for excess application of nitrogen. Again it was observed that the yield benefit for $150 \mathrm{~kg} \mathrm{~N} / \mathrm{ha}$ was $40.0 \%$ than the plants received no nitrogen, when average of two years' yield is considered. The result is in conformity with the findings of Rahman et al. (2004); Amin (1998); Setty et al. (1998); 


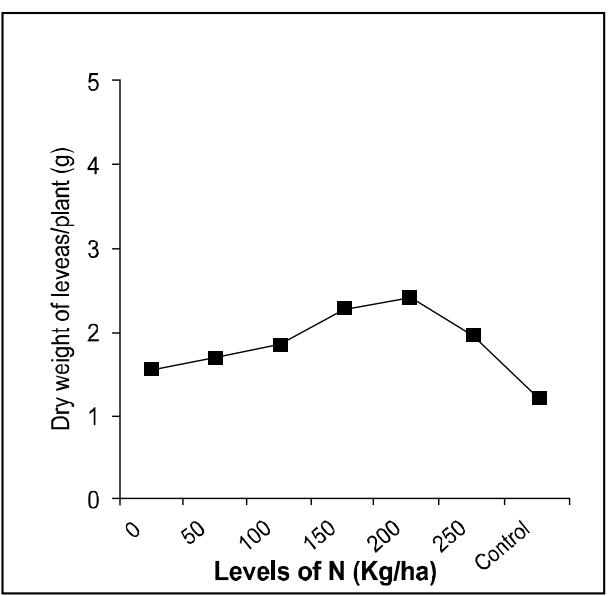

Fig. 1. Dry weight of leaves/plant (Average of two years) at maximum growth stage of plant.

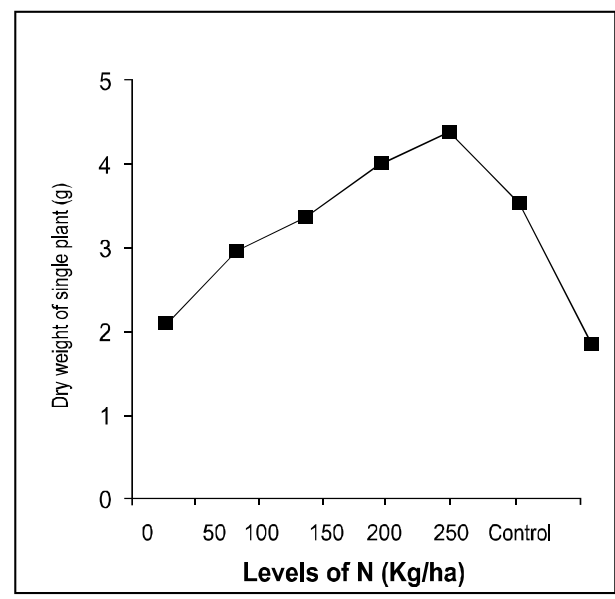

Fig. 2. Dry weight of single plant (Average of two years) at maximum growth stage of plant.

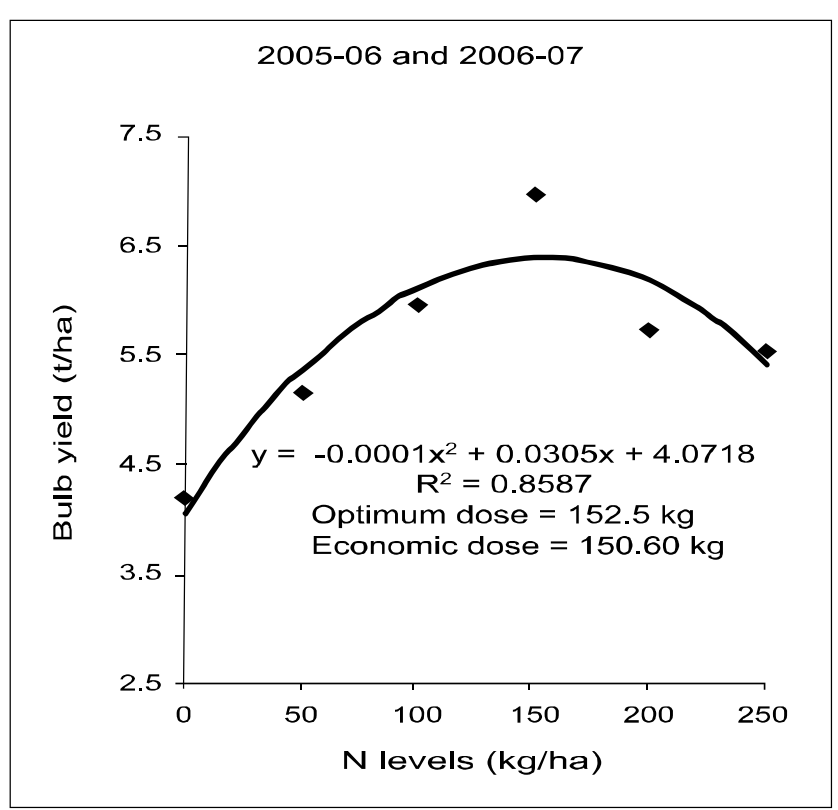

Fig. 3. Relationship between N levels bulb yield 


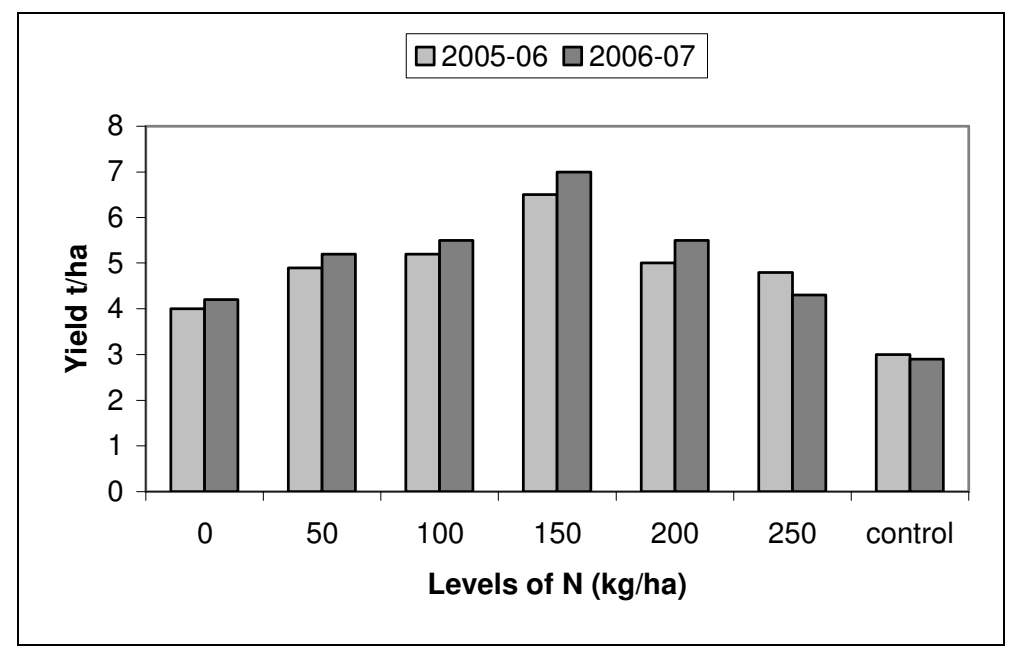

Fig. 4. Effect of different levels of $\mathrm{N}$ on the bulb yield of garlic in 2005-2006 and 2006-07.

Pandey and Singh (1993) and Uddin (1993). The average yield of nitrogen control treatment (No) was $4.18 \mathrm{t} / \mathrm{ha}$, which was lower from the average yield obtained from the plots fertilized with nitrogen. The increased yield for nitrogen supplementation was 18.8 to $40.0 \%$, when average of two years' yield is taken into account. A positive but quadratic relationship was observed between bulb yield and nitrogen doses when the data were regressed (Fig. 3). Higher coefficient of determination $\left(\mathrm{R}^{2}=0.8587\right)$ indicated that the regression model was a good fit, which implies that $86 \%$ variation in yield of garlic bulb could be attributed to the differences of nitrogen nutrition. From the regression equation, the optimum and economic dose of $\mathrm{N}$ were found to be 153 and $151 \mathrm{~kg} / \mathrm{ha}$. Beyond the said optimum rate, there is a possibility of loosing certain amount of yield.

\section{References}

Ali, M.Y. and M. F. Huq. 1996. Effect of nitrogen levels on the yield and storability of garlic. Bangladesh J. Agril. Res. 21(2): 328-333.

Amin, M. R.1998. Effects of different levels of nitrogen and potassium on the growth and yield of garlic. M. S. Thesis. Dept. of Hort. Bangladesh Agril. Univ., Mymensingh. p. 79.

BBS (Bangladesh Bureau of Statistics). 2006. Yearbook of Agricultural Statistics of Bangladesh, Sattistics Division, Ministry of Planning, Government of the People's Republic of Bangladesh, Dhaka 1215.

Bose, T. K. and M. G. Som. 1990. Vegetable Crops in India. Published by B. Mitra and Naya Prakash, Calcutta, India. pp.583-601. 
Brahma, S. and M. N. Yousuf. 2008. Effect of nitrogen and potassium on the growth and yield of garlic. Research Report for 2007-2008. Spices Research Centre, BARI Shibgong, Bogra. pp. 77-8 1.

Buwalda, J. G. and R. E. Freeman. 1987. Effect of nitrogen fertilizers on the growth and yield of potato, onion, garlic and hybrid squash. Scientia Hort. 33 (3/4): 61-173.

Cassman, K., A. Dobermann and D. Walters. 2002. Agroecosystems, nitrogen use efficiency and nitrogen management. Ambio 31(2): 132-140.

FAO (Food and Agriculture Organization). 1971. United Nations Development Programme. Soil Survey Project of Bangladesh. Soil Resources Technical Report. 3: 101-159.

Fritsch, F. N., N. G. Christian and E. R. Ferreya. 1990. Response of garlic (Allium sativum L.) cv. Espanol INIA to nitrogen fertilization. Investigation Agricola 10 (2): 85-89 [Cited from Hort., 66 (10): 990,1992].

Garcia, A. 1980. Sprouting before harvest in garlic. Commun. Tech. Emp. Bras. Pesqui. Agropecu. Pelotas 9: 3

Hedge, D.M. 1988. Effect of irrigation and nitrogen fertilizers on yield, quality, nutrient uptake and water use of onion (Allium cepa L.). Singapore J. Printice Hall of. India 16(2): 111-123.

Hossain, M. M. 1997. Effect of different levels of nitrogen and potash on the growth and yield of garlic. M.S. Thesis. Dept. of Hort., Bangladesh Agril. Univ., Mymensingh, p. 65.

Koltunov, V.A. 1984. Effect of different fertilizer rates and garlic productivity and storability. V'isn. Sil's kogospodars koi Nauki. 11 pp 52-54.

Kurian, J. C. 1995. Plant that heal. Oriental Watchman Publishing House, Pure, India.

Lachica, J. F. 1982. The effect of tillage, NPK levels and population density on the growth and yield of garlic. CLSU Scientia. J. 3 (2): 9-19.

Mitra, S. R. 1990. Garlic- Nutrition of vegetable crops. S. R. Mitra, M. K. Sadhu and T. K. Bose. Dept. Hort. Bidhan Chandra Krishi Viswavidyalaya. Naya Prokash ,Calcutta 700006: India. p 31.

Pandey, U. B. and D. K. Singh. 1993. Response of garlic to different levels of irrigation and nitrogen. Newsletter, National Hort. Res. Dev. Found. 13(3-4): 10-12.

Rahman, M. H., M. A. Rahim, M.T. A. Shah, M. M. Hossain and M. R. Islam. 2004. Effect of clove size and nitrogen on the growth and yield of garlic (Allium sativum L.), Bangladesh Seed Sci. \& Tech. 8 (1 \& 2): 2 1-25.

Rashid, M. M. 1996. Bangladesher Sabji (in Bangali), Bangla Academy, Dhaka. p 406.

Setty, B. S., G. S. Sulikeri and N. C. Hulamani. 1989. Effect of N, P and K on growth and yield of garlic (Allium sativum L.). Karnataka J. Agril. Sci. 2 (3): 160-164. 
Soto, J.A. 1988. Nutritional requirements of onion (Allium cepa L.) in the soils of northern cartago II. Critical levels for PK and S response to N. Agron. Costarricense 12 (1):52-57.

Talukder, A.F.M., M.A. Rahim and H.R.M.M. Anwar. 1998. Effect of planting time with different levels of nitrogen on the growth and yield of garlic. Bangladesh J. Train. Dev. $13(1 \& 2): 159-166$.

Uddin, A.F.M.J. 1993. Effect of planting time, nitrogen and potash levels on the growth and yield of garlic. M. Sc. Thesis, Dept. Hort., Bangladesh Agril. Univ., Mymensingh. p. 39.

Vachhani, M. U. and Z. G. Patel. 1993. Growth and yield of onion (Allium cepa L.) as influenced by nitrogen, phosphorus, and potash under South Gujrat condition. Prog. Hort. 25 (3-4):166-167.

Yousuf, M.A. and M. F. Huq. 1996. Effect of nitrogen levels on yield and storability of garlic. Bangladesh J. Agril. Res. 21 (2):328-333.3 